\title{
CURRENT TRENDS IN THE COLLECTION AND USE OF STATISTICS IN ACADEMIC AND PUBLIC LIBRARIES IN AFRICA
}

\author{
Elisha R. T. Chiware, Dept. of Information \& Communication Studies, \\ University of Namibia \\ Buhle Mbambo-Thata, Executive Director, Library Services, University \\ of South Africa
}

\begin{abstract}
This paper reports on the results of survey conducted to determine the current trends in the collection and reporting of library statistics in academic and public libraries in the Africa region. The literature shows that the present state of statistical data collection in many African university and public libraries is still backward and there are no uniform standards being followed in collection and reporting of statistics. The survey was conducted in July 2008 and shows that libraries use both manual and some automated systems to collect and compile library statistics. The survey also showed the need for African academic and public libraries to agree on a set of standards for the collection of statistics. The paper recommends that the IFLA Africa Section together with IFLA Section on Statistics and Evaluation, UNESCO, the Association of African Universities and national and university library organizations in Africa (SCNUL) should take a leading role building capacity of African libraries on the importance, collection and reporting of library statistics.
\end{abstract}

\section{INTRODUCTION}

Library statistics are a vital component for the management and promotion of all types of libraries in the world. In response to the IFLA Statistics and Evaluation Section's call for papers for the Library Statistics for the $21^{\text {st }}$ Century World post IFLA Conference held in Montreal, 18-19 the August, 2008, this paper reports on the situation of library statics in various regions of Africa. The paper focuses mainly on academic and public libraries. Africa as a vast continent has over the last decade been experiencing some notable economic developments although there are still many areas of marginalized development. The economic gains that some African countries are making should also be reflected in the provision of information services both in the public/community and education al/tertiary libraries. For any meaningful investment to be made in information services provision, there is need for a substantial body of statistical and economic data on existing library facilities and services to show where gaps exist and the current levels of expenditure, access to Internet/electronic resources, so that meaningful decisions can be made on how to invest in areas of greatest need. 
The collection of library statistics remains one of the most challenging management areas in African academic and public libraries. There remains no easily available source of up to date statistical and economic data on libraries in Africa. The value of statistics is as an advocacy and lobby tool to illustrate to policymakers, politicians and partners how libraries provide access to our cultural and scientific heritage; contribute to the development of knowledge economy; support the democratic process; help bridge the digital divide; support lifelong literacy; and represent good value for money (IFLA, 2003). It is in this spirit that several international organizations have attempted to coordinate the collection and reporting of library statistics in Africa in the past decades but without much success or continuity. The IFLA Section on Statistics and Evaluation for example aims to promote the compilation and use of statistics both in the successful management and operation of libraries and in the demonstration of the value of libraries outside the profession. It is concerned with the definition, standardization, collection, analysis, interpretation, publication, and use of statistical data from all types of library and information service activity (ILFA Section on Statistics, 2000). The International Organization for Standardization (ISO) has a standard on Information and Documentation - International library statistics; ISO 2789: 2006 which specifies rules for the library and information service community on the collection and reporting of statistics:

- For the purposes of international reporting;

- To ensure conformity between countries for those statistical measures that are frequently used by library managers but do not qualify for international reporting; and

- To encourage good practice in the use of statistics for the management of library.

The International Network for Availability of Scientific Publications (INASP) organized and funded a Workshop on the Collection and Use of Library Statistics in university libraries which took place in Zimbabwe in 1997. An Annual Statistical Return was drafted and three libraries; the University of Addis Ababa, the University of Dar es Salaam and the University of Zimbabwe, took part in a pilot statistics collection project. Statistical data from these three libraries was published in a volume entitled: Annual Library Statistics 1997/98. There was potential for other libraries in the African region to learn from the experiences of these three libraries and INASP (1999) proposed that:

- The three libraries that have started collecting and compiling statistics must be encouraged to continue. Only then will trends become visible to monitor performance from year to year;

- Other university libraries were to be encouraged to take part in the collection and compilation of library statistics. The usefulness of the statistics was to in- 
crease if more returns are received and data incorporated in the tables that were to be disseminated to more institutions globally;

- It was necessary for all libraries to put management processes in place, so as to ensure that the required statistics are collected, cumulated and produced at the end of each year; and

- It was also necessary to identify an organization, within Africa which will undertake:

o The maintenance and updating of the annual statistical return and its distribution to all university libraries in Africa; and

o The receipt of completed returns, the processing and checking of data, and the publication and distribution of the cumulative volume of annual library statistics.

The Association of African Universities (AAU) based in Ghana promised to continue the work of INASP, but ever since 1999, no other work has been done on the INASP initiative.

Another initiative on library statistics in African university libraries was launched by The International African Institute which published three volumes on: University Libraries in Africa: a review of their current state and future potential. The volumes were made up of case studies which include a range of statistical data including:

- Library collection sizes;

- Library staff;

- Expenditure interlibrary loans;

- Donor support; and

- Library use.

A number of African libraries are featured in the Global Library Statistics 19902000 compiled by IFLA using data from UNESCO and Libecon (2003). The Global library statistics covered areas of:

- Library servicing the public;

- Library collections;

- New media;

- Usage and users;

- Library staffing; and

- Library expenditure.

The data from Global Library Statistics covers data from several African countries in all the regions (Benin, Burkina Faso, Egypt, Equatorial Guinea, Gambia, Kenya, Malawi, Nigeria, Reunion, Senegal, Togo, Tunisia and Uganda). However the more recent work of Libecon does not include any further statistics from libraries in the African region. 
Lately, INASP has been involved in the provision of electronic services in various countries in Africa through its Programme for the Enhancement of Research Information (PERI). And as result of this initiative many African university libraries have access to various electronic databases and e-journals. INASP has initiated the monitoring and evaluation of the use of electronic databases (e-journals) in African university libraries. There is a book of case studies on monitoring and evaluation of electronic resources due for publication later this year.

The monitoring of e-resources use is critical for their continued and sustained success (Kiondo, 2005). According to Kiondo (2005) many university libraries in Africa however do not have software to monitor usage of e-resources. The University of Dar es Salaam (UDSM) for example relies on data collected through the following techniques:

a) Suppliers' data: usage statistics of electronic resources subscribed through PERI programme is provided by suppliers.

b) Library user statistics: usage data is collected from e-resource service points within the library. Users are required to register and indicate which e-resources they intend to use. Information collected includes name, status, year of study, faculty/department, title of e-resource, etc.

c) User queries: librarians monitor and analyze requests and questions from users on specific e-resources.

d) User surveys: the Library conducts periodic user surveys to gather key information about resources and services.

Initially conducted to address a concern of stakeholders on the apparent limited use of e-resources at UDSM, surveys were conducted in 2004 and 2005. They first examined the extent of e-resource use and factors that might influence use. The findings were instrumental in intensifying marketing of e-resources and implementing an information literacy programme. The second survey also investigated whether increased user access to e-resources has had an impact on the teaching and learning processes of the university. The techniques used in the survey included self-administered questionnaires and face-to-face interviews with selected key users to get in-depth insights into patterns of use and factors that might hinder or facilitate use of e-resources. Additionally, group discussions and workshops were held, in which stakeholders provided further input on the way forward (Kiondo, 2005).

National libraries have seen the need of getting consensus on performance indicators for assessing the quality of their services and several groups within IFLA section of National Libraries and CENL (Foundation Conference of European National Librarians) (Poll, 2008). The collection of statistics in public libraries in Africa has not been well documented or supported in the past. De Jager and Nassimbeni (2005) report on the efforts in South Africa to standardize the collection of statistics in public libraries. With funding from the Carnegie Corporation of New York, a Working Group on Public Library Statistics (WGPLS) was established by 
the Libraries Working Group to facilitate the drafting of a simple form for regular collection of statistics from public libraries so that the envisioned three databases could be kept up to date through:

a) A library directory containing identification and descriptive data about libraries;

b) A demographic database containing relevant demographic information; and

c) A geographic database containing geographical information such as municipal boundaries and location data for the libraries.

As a result of the above efforts, the National Library of South Africa started to distribute the statistics collection form to public libraries throughout South Africa and it was hoped that this could be the beginning of building a culture of assessment in South African public libraries. Elsewhere in Africa, there is also need to build capacity so that national and community libraries start to account for various activities and use the assessment of service provision to argue for more funds from governments and donors so that more people have access to library facilities.

\section{RESEARCH OBJECTIVES}

The objectives of the survey on the collection of and use of library statistics in African academic and public libraries were therefore to determine:

- The type of statistics collected in African academic and public libraries;

- The methods used to collect the statistics;

- The types of information technology tools used in the collection of statistics; and

- The use of the statistics collected.

\section{RESEARCH METHODOLOGY}

A descriptive research approach was applied in order to collect data from academic, national and public libraries throughout Africa. Data was collected through a self-administered questionnaire emailed to respondents, containing structured questions with a combination of structured (closed) and unstructured (open-ended) responses. The first part of the questionnaire focused on whether or not the libraries collect library statistics. The second part of the questionnaire aimed at obtaining information regarding the type of library statistics collected, while the third part concentrated on the methods used for collecting library statistics. In order to gain a picture of the current trends regarding library statistical activities on the continent, we selected 5 countries in the four regions in Africa i.e. West, East, South and North Africa. In each of the countries selected, two institutions (an academic library and a public library were selected). 
Data collection took place during July 2008. The Statistical Package for Social Sciences (SPSS) was used to analyze the data. Frequencies were calculated for categorical variables and, where applicable, the results were reported in terms of demographical information.

\section{RESULTS OF THE SURVEY}

\section{Response rate and respondents}

When respondents understand the purpose of the survey and the significance of their responses, they are more likely to participate. A cover letter was included with the questionnaire clearly stated the purpose of the survey and the importance of participation by respondents. One hundred and thirty two (132) questionnaires were emailed throughout Africa. Twenty eight (28) emails were returned as undeliverable. Altogether, 18 completed questionnaires were returned by 4 August 2008. In other words, there was an overall response rate of $17.3 \%$. The profile of the number of libraries who participated in this study is reflected in Table 1 below. The table also indicates the percentage of academic, national and public libraries participating in this survey.

Table 1: Number of Libraries Participating in this Survey

\begin{tabular}{|l|c|c|c|}
\hline Country & Academic libraries & National libraries & Public libraries \\
\hline Cameroon & 1 & & \\
\hline Egypt & 1 & & \\
\hline Ghana & 2 & & \\
\hline Namibia & 1 & 1 & \\
\hline Nigeria & 7 & & \\
\hline South Africa & 1 & & \\
\hline Tanzania & 15 & & 2 \\
\hline TOTAL & & & \\
\hline
\end{tabular}


From Table 1, it is evident that the majority of respondents $(81 \%)$ were academic libraries.

\section{The collection of library statistics}

All 18 libraries participating in this survey indicated that they collect library statistics.

The reasons for collecting library statistics are reflected in Table 2 below.

Table 2: Reasons for Collecting Library Statistics

\begin{tabular}{|l|c|}
\hline Reason & Percentage (\%) \\
\hline To monitor performance & $92.3 \%$ \\
\hline To assist in policy formation & $76.9 \%$ \\
\hline To market library services & $53.8 \%$ \\
\hline To help in obtaining more funding & $69.2 \%$ \\
\hline To analyse and predict trends & $76.9 \%$ \\
\hline \begin{tabular}{l} 
To assist in management and decision-making processes \\
\hline $\begin{array}{l}\text { Other reasons: increasing readership, annual reports of the or- } \\
\text { ganization, quality control (benchmarking), monitoring turn- } \\
\text { away stats for databases which influence decisions to increase } \\
\text { user licences. }\end{array}$
\end{tabular} \\
\hline
\end{tabular}

The two most important reasons for collecting library statistics are shown in Table 2 above. Ninety two percent $(92.3 \%)$ of all libraries indicated that they collect library statistics to monitor performance, while $84.6 \%$ said that collecting library statistics assists them in management and decision-making processes and $76.9 \%$ in policy formulation and to analyze trends. A further $69.2 \%$ indicated that statistics were collected to help in obtaining more funding for the libraries.

\section{The types of library statistics collected}

Table 3 below reflects the different types of library statistics collected, as well as the percentage per type collected by the respondents. 


$\left.\begin{array}{|l|c|}\hline \text { Type } & \text { Frequency } \\ \hline \text { Number of loans } & 85.7 \% \\ \hline \text { Use of electronic databases } & 71.4 \% \\ \hline \text { Number of e-resources in the library } & 57.1 \% \\ \hline \text { Number of downloads per person } & 42.9 \% \\ \hline \text { Number of library visitors } & 64.3 \% \\ \hline \text { Weekly opening hours } & 35.7 \% \\ \hline \text { Number of reference questions } & 64.3 \% \\ \hline \text { Registered number of library users } & 57.1 \% \\ \hline \text { Library staff } & 71.4 \% \\ \hline \text { Size of library collections } & 64.3 \% \\ \hline \text { Size of library budget } & 64.3 \% \\ \hline \text { Library expenditure } & 71.4 \% \\ \hline \text { Library use training } & 64.3 \% \\ \hline \text { Library acquisitions (i.e. requests, ordering, receipt) } & 85.7 \% \\ \hline \begin{array}{l}\text { Library materials processing (i.e. cataloguing and classifica- } \\ \text { tion) }\end{array} & 78.6 \% \\ \hline \text { Library seating capacity } & 50 \% \\ \hline \text { Library shelving } & 23.1 \% \\ \hline \text { Events in the library } & 42.9 \% \\ \hline \begin{array}{l}\text { Other: number of pages updated on the library's website, } \\ \text { added to the information resources, ILL fill rates, gate }\end{array} & \text { Internet Café, use of periodicals, in-house } \\ \hline\end{array}\right)$


Table 4: Frequency of Collection Per Type of Library Statistics

\begin{tabular}{|c|c|c|c|c|c|}
\hline Type & Daily & Weekly & Monthly & Quarterly & Annually \\
\hline Number of loans & $41.7 \%$ & & $33.3 \%$ & $16.7 \%$ & $8.3 \%$ \\
\hline $\begin{array}{l}\text { Use of electronic } \\
\text { databases }\end{array}$ & $20 \%$ & & $40 \%$ & $30 \%$ & $10 \%$ \\
\hline $\begin{array}{l}\text { Number of e-resources in } \\
\text { the library }\end{array}$ & $25 \%$ & & $25 \%$ & $25 \%$ & $25 \%$ \\
\hline $\begin{array}{l}\text { Number of downloads per } \\
\text { person }\end{array}$ & $50 \%$ & & $33.3 \%$ & & $16.7 \%$ \\
\hline Number of library visitors & $55.6 \%$ & $11.1 \%$ & $22.2 \%$ & $11.1 \%$ & \\
\hline Weekly opening hours & $20 \%$ & & $60 \%$ & & $20 \%$ \\
\hline $\begin{array}{l}\text { Number of reference } \\
\text { questions }\end{array}$ & $22.2 \%$ & & $44.5 \%$ & $22.2 \%$ & $11.1 \%$ \\
\hline $\begin{array}{l}\text { Registered number of } \\
\text { library users }\end{array}$ & $12.5 \%$ & & $25 \%$ & $25 \%$ & $37.5 \%$ \\
\hline Library staff & $10 \%$ & & $20 \%$ & $40 \%$ & $30 \%$ \\
\hline Size of library collections & $11.1 \%$ & & $11.1 \%$ & $44.5 \%$ & $33.3 \%$ \\
\hline Size of library budget & $11.1 \%$ & & $11.1 \%$ & $33.3 \%$ & $44.5 \%$ \\
\hline Library expenditure & $20 \%$ & & $50 \%$ & $20 \%$ & $10 \%$ \\
\hline Library use training & $11.1 \%$ & & $55.6 \%$ & $22.2 \%$ & $11.1 \%$ \\
\hline $\begin{array}{l}\text { Library acquisitions (i.e. } \\
\text { requests, ordering, } \\
\text { receipt) }\end{array}$ & $33.3 \%$ & & $33.3 \%$ & $16.7 \%$ & $16.7 \%$ \\
\hline $\begin{array}{l}\text { Library materials } \\
\text { processing (i.e. } \\
\text { cataloguing and } \\
\text { classification) }\end{array}$ & $27.3 \%$ & & $45.4 \%$ & $18.2 \%$ & $9.1 \%$ \\
\hline Library seating capacity & $14.3 \%$ & & $42.8 \%$ & $14.3 \%$ & $28.6 \%$ \\
\hline Library shelving & $20 \%$ & & $20 \%$ & $20 \%$ & $40 \%$ \\
\hline Events in the library & $16.7 \%$ & $16.7 \%$ & $16.7 \%$ & $16.7 \%$ & $33.2 \%$ \\
\hline Other & $50 \%$ & & $25 \%$ & $25 \%$ & \\
\hline
\end{tabular}


The main types of statistics collected by libraries are the number of loans $(85.7 \%)$, library acquisitions $(85.7 \%)$, library materials processing $(78.6 \%)$, use of electronic databases $(71.4 \%)$, number of library staff $(71.4 \%)$ and library expenditure (71.4\%).

Table 4 provides information about how frequently libraries collect the different types of statistics.

\section{Frequency of compilation of statistical reports}

Figure 1 indicates that $92.9 \%$ of all respondents compiled a statistical report annually, while $50 \%$ also compiled statistical reports on a monthly and quarterly basis.

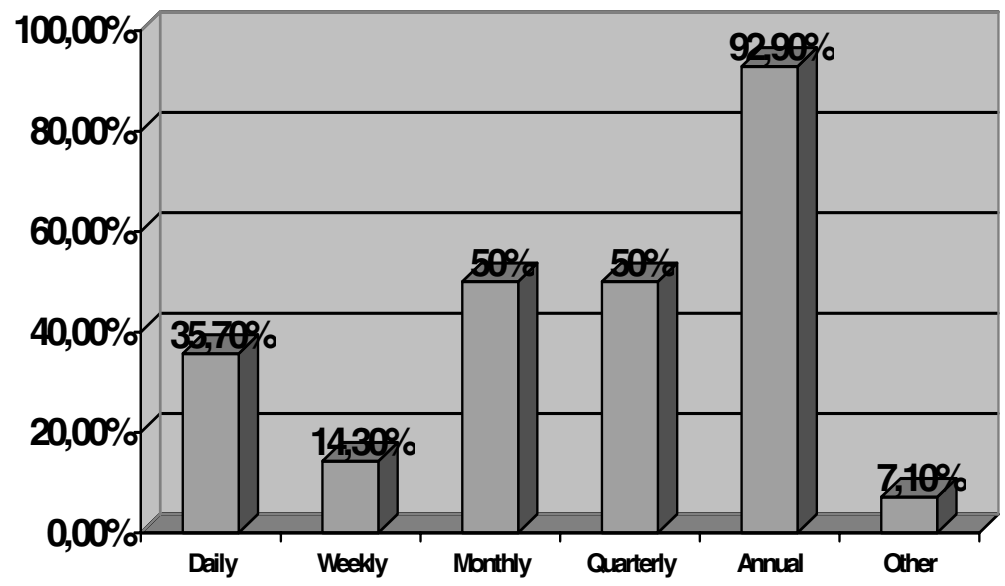

Figure 1: Compilation of statistical reports

\section{Publications in which library statistics are included}

The respondents were required to indicate the type of publications in which collected library statistics are published. The libraries indicated that they publish statistics in a wide range of publications and include the following:

- Annual reports / municipal annual reports

- Brochures

- Departmental reports

- Faculty board meetings

- Library Committee quarterly and annual reports

- Library director's reports

- Monthly reports

- Newsletters / Library newsletters

- Quarterly reports 
- Research reports of the university (Annual)

- Self-evaluation reports

- Stats-at-a-glance that appear on the intranet

- University senate reports

\section{Responsibility for the collection, compilation and analysis of statistics}

The respondents were required to indicate who collects, compiles and analyses library statistics from different sections of the library. The sections responsible are shown in the table below (Table 5). A high percentage of respondents (92.9\%) said that each responsible section or department collects, compiles and analyses their own statistics.

Table 5: Responsibility For Different Library Sections' Statistics

\begin{tabular}{|l|c|}
\hline Responsibility & Percentage (\%) \\
\hline Each section or department & $92.9 \%$ \\
\hline IT section & $35.7 \%$ \\
\hline Management & $50 \%$ \\
\hline $\begin{array}{l}\text { Other: person/s responsible for management information and } \\
\text { quality assurance }\end{array}$ & $7.1 \%$ \\
\hline
\end{tabular}

The respondents were also required to indicate who collects, compiles and analyses library statistics for the whole library. The sections responsible are shown in the table below (Table 6). Just over seventy-one percent of all respondents $(71.4 \%)$ indicated management as being responsible for the collection, compilation and analysis of statistics for the whole library.

Table 6: Responsibility for Statistics of the Whole Library

\begin{tabular}{|l|c|}
\hline Responsibility & Percentage (\%) \\
\hline Each section or department & $57.1 \%$ \\
\hline IT section & $14.3 \%$ \\
\hline Management & $71.4 \%$ \\
\hline $\begin{array}{l}\text { Other: person/s responsible for management information and } \\
\text { quality assurance }\end{array}$ & $7.1 \%$ \\
\hline
\end{tabular}




\section{Manual and/or electronic collection of library statistics}

Table 7 below provides information about respondents' feedback with regard to the manual and/or electronic collection of library statistics. It appears from this table that most respondents (78.6\%) are collecting statistics both manually and electronically.

Table 7: Manual and/or Electronic Collection of Statistics

\begin{tabular}{|l|c|}
\hline Collection method & Percentage (\%) \\
\hline Only manual & $14.3 \%$ \\
\hline Only electronic & $7.1 \%$ \\
\hline $\begin{array}{l}\text { Use manual and electronic methods, depending on the type } \\
\text { of statistics collected }\end{array}$ & $78.6 \%$ \\
\hline
\end{tabular}

Manual collection is usually done on a daily basis by physically counting items/ users. These statistics are then forwarded to the person responsible for the library management information system.

Table 8 below reflects the specific types of statistics, as well as the method of collection and type of software used, where applicable.

\section{Comments from respondents}

The last part of the survey required that respondents comment on their overall impressions about the collection and use of statistics in African academic and public libraries. The comments include the following:

a) 'As the library is catering for the illiterate community and the disabled, we are keeping the statistics of both categories so that we can be able to cater for their needs.'

b) 'The collection of statistics remains a difficult area because each library collects them in a different way. To compile comparative data, it is important that libraries agree to collect a core set of data the same way. CHELSA (Council for Higher Education Libraries in South Africa) has gone some way to provide guidelines to do this but it has not been implemented. The challenge is who will maintain a database of comparative data - there are sustainability and affordability issues to be addressed.'

c) 'The use of statistics in Namibia is still mainly manually based and uncoordinated. It would be ideal to have a national statistics collection method - ideally coordinated by the National Library, which would be published for wider dissemination. Statistics play a very important role in lobbying and in inform- 
ing library management on collection development and addressing areas of weakness. In terms of the National Library, efforts to improve the collection of statistics are being considered, as the present areas of statistics collection need to be widened.'

d) 'Collection of statistics has helped our library achieve the following in the past 5 years:

o A new library building to accommodate the ever increasing number of students. The seating capacity increased from 100 to 952.

o An increase in the library book vote, as we aim to have a 3 books/student ratio. The current book/student ratio is 1:7.

o Statistics will help us obtain a separate post-graduate vote, to enable us to purchase the graduate programmes collection, which is adequate to support the programmes.

o The statistics will assist the library in achieving a student/computer ratio of 5:1. Currently, the whole institution has a 7:1 ratio.'

From the above comments, it is clear that, there is need for clear standards in Africa regarding the collection and use of library statistics. Ministries responsible for national libraries and higher education libraries need to address this issue urgently as it will help in the development of these facilities in the long run. Without a reliable body of library statistics from Africa, it will be very difficult to measure the progress in implementing social and economic development programmes especially the Millennium Development Goals (MDGs) and the achievement of the goals and objectives of the African Information Society Initiative (AISI).

\section{RECOMMENDATIONS AND CONCLUSION}

Although the response rate was not very impressive, the survey was able to establish some positive aspects from the respondents that include the following:

- The collection of library statistics is an essential foundation for quality library services;

- This survey provides a current picture of African libraries with regard to the trends in collection and use of statistics;

- It is important for addressing weaknesses in African library and information services; and

- It provides comparative library data.

The survey also registered some areas that need improvement and these are:

- There is no standard on the type of library statistics to be collected;

- There is no shared position on how data must be collected, analyzed, presented and applied; 
Table 8: Types Of Statistics, Collection Methods And Software

\begin{tabular}{|c|c|c|c|}
\hline Type of activity & $\begin{array}{c}\text { Manual } \\
\text { collection }\end{array}$ & $\begin{array}{l}\text { Electronic } \\
\text { collection }\end{array}$ & Type of software \\
\hline Number of loans & $9.1 \%$ & $90.9 \%$ & $\begin{array}{l}\text { ADLIB } \\
\text { Aleph } \\
\text { Innopac Report Module } \\
\text { ITS } \\
\text { Millennium } \\
\text { PALS }\end{array}$ \\
\hline Electronic databases & & $100 \%$ & $\begin{array}{l}\text { CDS ISIS } \\
\text { ITS }\end{array}$ \\
\hline E-resources & $25 \%$ & $75 \%$ & $\begin{array}{l}\text { Aleph } \\
\text { Done by vendors (Tanzania) } \\
\text { Excel \& Counter compliant } \\
\text { software } \\
\text { Millennium } \\
\text { TDNet }\end{array}$ \\
\hline Downloads & $33.3 \%$ & $66.7 \%$ & \\
\hline Library visitors & $50 \%$ & $50 \%$ & ICAM CSGold \\
\hline $\begin{array}{l}\text { Questions/Reference } \\
\text { queries }\end{array}$ & $71.4 \%$ & $28.6 \%$ & $\begin{array}{l}\text { Aleph } \\
\text { DotNet program } \\
\text { QuestionPoint } \\
\end{array}$ \\
\hline Library users & $33.3 \%$ & $66.7 \%$ & $\begin{array}{l}\text { Innopac Report Module } \\
\text { ITS } \\
\text { Millennium }\end{array}$ \\
\hline Library staff & $83.3 \%$ & $16.7 \%$ & Oracle \\
\hline Size of collection(s) & $16.7 \%$ & $83.3 \%$ & $\begin{array}{l}\text { Aleph } \\
\text { Millennium }\end{array}$ \\
\hline Library budget & $25 \%$ & $75 \%$ & $\begin{array}{l}\text { ITS System } \\
\text { PROMIS }\end{array}$ \\
\hline Library expenditure & $20 \%$ & $80 \%$ & $\begin{array}{l}\text { ITS } \\
\text { Millennium } \\
\text { Oracle } \\
\text { Protea (University } \\
\text { Management Information } \\
\text { System) }\end{array}$ \\
\hline
\end{tabular}




\begin{tabular}{|c|c|c|c|}
\hline Type of activity & $\begin{array}{l}\text { Manual } \\
\text { collection }\end{array}$ & $\begin{array}{l}\text { Electronic } \\
\text { collection }\end{array}$ & Type of software \\
\hline User training & $88.9 \%$ & $11.1 \%$ & Excel \\
\hline Acquisitions & $18.2 \%$ & $81.8 \%$ & $\begin{array}{l}\text { Aleph } \\
\text { Excel } \\
\text { Innopac Report Module } \\
\text { ITS } \\
\text { Millennium }\end{array}$ \\
\hline $\begin{array}{l}\text { Library materials } \\
\text { processing (i.e., } \\
\text { cataloguing and } \\
\text { classification) }\end{array}$ & $27.3 \%$ & $90.9 \%$ & $\begin{array}{l}\text { Aleph } \\
\text { Innopac Report Module } \\
\text { ITS } \\
\text { Millennium } \\
\text { OCLC } \\
\text { Prolib }\end{array}$ \\
\hline $\begin{array}{l}\text { Library seating } \\
\text { capacity }\end{array}$ & $100 \%$ & & \\
\hline Library shelving & $100 \%$ & & \\
\hline Events in the library & $100 \%$ & & \\
\hline $\begin{array}{l}\text { Periodicals and/or } \\
\text { serials use }\end{array}$ & $50 \%$ & $50 \%$ & $\begin{array}{l}\text { Aleph } \\
\text { Millennium }\end{array}$ \\
\hline Interlibrary loans & $50 \%$ & $50 \%$ & $\begin{array}{l}\text { Aleph } \\
\text { ReQuest Module }\end{array}$ \\
\hline Literature searches & $100 \%$ & & \\
\hline Book requests & $100 \%$ & & \\
\hline Photocopies & $100 \%$ & & \\
\hline Internet use & $100 \%$ & & \\
\hline Opening hours & $100 \%$ & & \\
\hline Gate count & $50 \%$ & $50 \%$ & $3 \mathrm{M}$ \\
\hline Institutional repository & $50 \%$ & $50 \%$ & ePrints \\
\hline Donations & $100 \%$ & & Aleph \\
\hline Multimedia & $50 \%$ & $50 \%$ & Aleph \\
\hline
\end{tabular}


- There is a wide gap in the type and frequency of statistics between technologically advanced libraries and those less fortunate; and

- There is no national or African database of comparative library statistics available.

The future of collection and compilation of library statistics on a continental scale depends on many issues that need to be addressed by the libraries themselves and a number of international organizations working towards the development of libraries in Africa. It is recommended that:

- The IFLA Africa Section should work closely with the Statistics and Evaluation Section to build capacity among African libraries to collect library statistics. Such efforts could include the running of workshops and coming up with agreed standards for the various types of libraries.

- The African Association of African Universities and the Standing Conference of African National University Libraries of Eastern, Central and Southern Africa (SCANUL-ECS) and the Standing Conference of African University Libraries, Western Area (SCAULWA) should all play leading roles in guiding university and public libraries on collection and reporting of statistics; and

- A regional workshop on capacity building should be held soon on issues of statistics usage and management and UNESCO, IFLA and ISO provide the technical expertise.

The collection of statistics in other areas in Africa seems to be done with a certain degree of success. The Demographic and Health Surveys (DHS) carried out throughout Africa by ORC Macro in conjunction with national bureau of statistics and health ministries have over the years produced a reliable source of data for both planning and implementing of social and economic programmes. This experience of DHS surveys should be used by the library community to develop standards on the collection and reporting of library statistics. UNESCO with its experience in collecting education statistics globally could also help in conjunction with International Standards Organization (ISO) to implement the ISO 2789:2006 (which specifies rules for library and information services community on the collection and reporting of statistics)

\section{REFERENCES}

De Jager, Karin and Nassimbeni, Mary (2005), 'Towards measuring the performance of public libraries in South Africa', South African Journal of Library and Information Science, 71 (1), 39-50.

Fuegi, David (1999). LIBECON2000 and the future of international library statistics. Paper presented at the $65^{\text {th }}$ IFLA Council and General Conference, Bangkok, Thailand 20-28 August, 1999. 
IFLA (International Federation of Library Associations and Institutions) (2003). Global Library Statistics 1990-2000.

IFLA Section on Statistics (2000). Annual Report, 2000.

INASP (1999). University Libraries in Africa: Annual Library Statistics 1997/98: Addis Ababa University, Ethiopia, University of Dar es Salaam, Tanzania, And University of Zimbabwe. Oxford: INASP

International African Institute (1997). University libraries in Africa: a review of their current state and future potential. 3 vols. London: International African Institute

Poll, Roswitha (2008). Quality indicators for National Libraries: the new standard. Paper presented at the $74^{\text {th }}$ IFLA General Conference and Council, 1014 August, 2008, Quebec, Canada.

Willemse, John (1989). 'Library effectiveness - the need for measurement', South African Journal of Library and Information Science, 57(3), 261-266.

Kiondo, Elizabeth (November, 2005'). Monitoring and evaluating e-resources use at the University of Dar es Salaam Library', INASP Newsletter, No. 30, [Online] retrieved on 27/09/2008 available at: http://www.inasp.info/uploaded/ documents/30-nov05.html 